\title{
原著 糖尿病患者の血糖コントロール基準としてのHbAI
}

\begin{tabular}{|c|c|c|c|c|c|}
\hline \multicolumn{6}{|c|}{ 神戸大学医学部第二内科 } \\
\hline 老粐 & 宗忠॰ & 石川 & 和夫 & 川崎 & 富泰 \\
\hline 窪田 & 伸三 & 高木 & 潔 & 丹家 & 元陽 \\
\hline 吉村 & 幸男 & 馬場 & 茂明 & & \\
\hline
\end{tabular}

$\mathrm{HbAI}$ as a monitor of blood glucose in diabetic treatment

Munetada OIMOMI, MD, Kazuo IsHIKAWA, MD, Tomihiro KAWASAKI, MD,

Shinzo Kubota, MD, Kiyoshi TAKagI, MD Genyo TANKe, MD,

Yukio YoshimuRA, MD and Shigeaki BABA, MD

The Second Department of Internal Medicine, Kobe University School of Medicine, Kobe

概要 Hemoglobin AI（HbAI）扣よびHbAICを糖尿病患者の血糖コントロール基準として 臨床応用する場合，なお二，三の問題があり，今回それらの問題を検討し，以下の結論をえた。 1) HbAI あるいはHbAIC は糖求病患者の約 1 力月前の血糖コントロール状態を示す指標とな る．2）榶尿病患者の血糖コントロールの目標值はHbAIで $9 \%$ ，HbAICで $6 \%$ とした，3）梼 尿病患者では，labile $\mathrm{HbAI} / \mathrm{HbAr}$ 健常者との間に差はなく，約13\%であつた，4）不安定型 糖疗病症例では，健常者と比較してlabile HbAI值拉よびlabile HbAI/HbAI值は共に大であつ た。

\section{緒言}

糖尿病患者の長期の血糖コントロールの指標と して，HbAIあるいはHbAICが用いられてきた。 しかしながら，HbAIあるいはHbAICを臨床応用 する場合，どれ程以前の血糖コントロールを反映 しているのかを追求した報告は, Koenigらの臨床 経過例1)，あるいはGabbayらによる尿糖排泄量と HbAIとの関係をみたもの放などがあるが，詳細な 成績を示したものは少ない，さらにHbAIあるい はHbAICによる血糖コントロールの目標值の設 定などの若干の問題がある。そこでHbAI, HbAIC を血糖コントロール基準として臨床応用する場合 のこれら $2 \sim 3$ の問題点を検討した.

\section{方法およひ対象}

HbAI 並びにHbAic の測定にはColeらの方法3) 改良し， $1 \times 10 \mathrm{~cm}$ のカムにBio Rex 70 (minus 400 mesh）を用いてイオン交換クロマトグラ フィーを行なつた。 bufferとしてはpH 6.65，およ

[昭和58年 3 月 11 日受稿]
びpH 6.45のphosphate bufferを用い, 高速液体ク ロマトグラフィー（HPLC）を使用してHbAIおよ びHbAICを測定しだ).

HbAI のlabile HbAI 分画を除去する方法 ${ }^{51}$ とし て, 30mM semicarbazide, $12 \mathrm{mM}$ anilineを洗浄 赤血球に添加し, $37^{\circ} \mathrm{C}$ で, 30 分間のincubationを行 なつた. incubation前後の赤血球でHbAI值を測定 し， labile HbAl分画を算出した。

糖尿病患者を血糖コントロール良好群，血栯コ ソトロール不良群, impaired glucose tolerance 群，不安定型糖尿病群に分けた，血糖コントロー ル良好例としては 1 力月前の空腹時血糖 (FBS), 並びにHbAI および HbAIC 採血時のFBSが120 $\mathrm{mg} / \mathrm{dl}$ 以下,さらに過去 1 力月間の 1 日尿糖量が5 g以下で，この間低血糖のなかつた症例とした。本 群の 1 力月前のFBSの平均は $100.6 \pm 4.5 \mathrm{mg} / \mathrm{dl}$, 採血時点のFBSの平均は101.1 $1 \pm 5.1 \mathrm{mg} / \mathrm{dl}$ (Mean士SE)であつた．血糖コントロール不良例 としては 1 カ月前のFBS，並びにHbAI括よび $\mathrm{HbAIC}$ 採血時のFBSが $200 \mathrm{mg} / \mathrm{dl}$ 以上の症例とし 
た. 今回の不安定型糖尿病症例はtype Iの糖㽷病 症例で,しばしば 1 日の血糖変動が少なくとも200 $\mathrm{mg} / \mathrm{dl}$ 以上ある症例とした。 なお，コントロール良 好例, 不安定型糖尿病例は入院観察可能な症例の みとした。

\section{成 績}

タトアシドーシス，あるいは不安定型糖尿病症 例を除いた糖疗病症例のFBSと $\mathrm{HbAI}$ ，並びに HbAIcとの相関をみた (Table 1). HbAIはHbAI 採血時点より遡つて $3 \sim 4$ 週前の FBS と $\mathrm{r}=$ 0.762 と最も良好な相関がみられた。 HbAICにつ いても同様に $3 \sim 4$ 週前のFBSとの間で, $\mathrm{r}=$ 0.757 と最も良好な相関がみられた。一方，HbAI, HbAIC は共 $K 5 \sim 6$ 週前 $\mathrm{r}=0.439, \mathrm{r}=0.401,7$ ～ 8 週前 $r=0.571, r=0.558$ とそれぞれ軽度の相関 がみられたが， 3ー4 週前のFBSに比較して相関

Table 1. Correlation between $\mathrm{HbAl}$ and $\mathrm{HbAic}$ antecedent FBS.

\section{Correlation of $\mathrm{HbA}_{1}$ to antecedent FBS}

\begin{tabular}{|c|c|c|c|c|}
\hline $\begin{array}{c}\text { FBS } \\
\text { collection }\end{array}$ & $n$ & $\begin{array}{l}\text { linear regression } \\
\text { equation }\end{array}$ & $r$ & \\
\hline immediate $(0 \sim 3$ days $)$ & 77 & $y=4.0 x+78.1$ & 0.268 & $P<0.05$ \\
\hline 1 week $(4 \sim 10$ days $)$ & 32 & $y=5.1 x+90.5$ & 0.263 & $P<0.2$ \\
\hline 2 weeks $(11 \sim 17$ days $)$ & 52 & $y=9.8 x+21.2$ & 0.513 & $P<0.001$ \\
\hline $3 \sim 4$ weeks (18 $\sim 31$ days) & 54 & $y=14.4 x-30.7$ & 0.762 & $P<0.001$ \\
\hline $5 \sim 6$ weeks $(32 \sim 45$ days $)$ & 49 & $y=10.0 x+22.3$ & 0.439 & $P<0.01$ \\
\hline $7 \sim 8$ weeks ( $46 \sim 59$ days) & 59 & $y=11.3 x+5.7$ & 0.571 & $P<0.001$ \\
\hline
\end{tabular}

\section{Correlation of $\mathrm{HbA}_{1} \mathrm{c}$ to antecedent FBS}

\begin{tabular}{lccccc}
\hline $\begin{array}{c}\text { FBS } \\
\text { collection }\end{array}$ & $n$ & $\begin{array}{l}\text { linear regression } \\
\text { equation }\end{array}$ & $r$ & \\
\hline \hline immediate $(0 \sim 3$ days $)$ & 77 & $y=2.6 x+106.0$ & 0.141 & $P<0.3$ \\
\hline 1 week & $(4 \sim 10$ days $)$ & 32 & $y=6.6 x+95.8$ & 0.301 & $P<0.1$ \\
\hline 2 weeks $(11 \sim 17$ days $)$ & 52 & $y=12.2 x+40.2$ & 0.518 & $P<0.001$ \\
\hline $3 \sim 4$ weeks $(18 \sim 31$ days $)$ & 54 & $y=17.7 x-1.7$ & 0.757 & $P<0.001$ \\
\hline $5 \sim 6$ weeks (32 45 days) & 49 & $y=10.3 x+58.2$ & 0.401 & $P<0.01$ \\
\hline $7 \sim 8$ weeks (46 59 days) & 59 & $y=12.8 x-36.2$ & 0.558 & $P<0.001$ \\
\hline
\end{tabular}

Table 2. HbAI and HbAic levels in normal subjects and diabetics

The data represent the mean \pm S.D.

${ }^{\mathrm{a}} \mathrm{p}<0.001$ versus normal subjects, ${ }^{b} \mathrm{p}<0.005,{ }^{\mathrm{c}} \mathrm{p}<$ 0.001 versus impaired glucose tolerance.

\begin{tabular}{lcc} 
& \multicolumn{1}{c}{ HbA $_{1}$} & ${ }^{\mathrm{HbA}}{ }_{1 \mathrm{c}}$ \\
\hline $\begin{array}{l}\text { Normal subjects } \\
\mathrm{n}=25\end{array}$ & $6.9 \pm 0.7$ & $4.3 \pm 0.6$ \\
$\begin{array}{l}\text { Patlents with tmpaired } \\
\text { glucose tolerance } \\
\mathrm{n}=24\end{array}$ & $8.4 \pm 0.9^{\mathrm{a}}$ & $5.7 \pm 0.6^{\mathrm{a}}$ \\
$\begin{array}{l}\text { Good controlled } \\
\text { diabetic patients } \\
\mathrm{n}=22\end{array}$ & $9.2 \pm 1.3^{\mathrm{a}} \mathrm{b} 6.1 \pm 1.1^{\mathrm{a}} \mathrm{c}$ \\
\end{tabular}

係数の低下がみられた。

血糖コントロール良好例を選択し，その $\mathrm{HbAI}$ およびHbAICを求めた(Table 2). 健常者のHbAI,

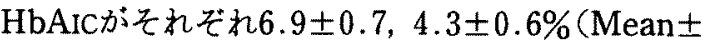
SD）であるのに対し，血糖コントロール良好な糖

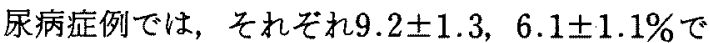
あつた.なおimpaired glucose tolerance群の
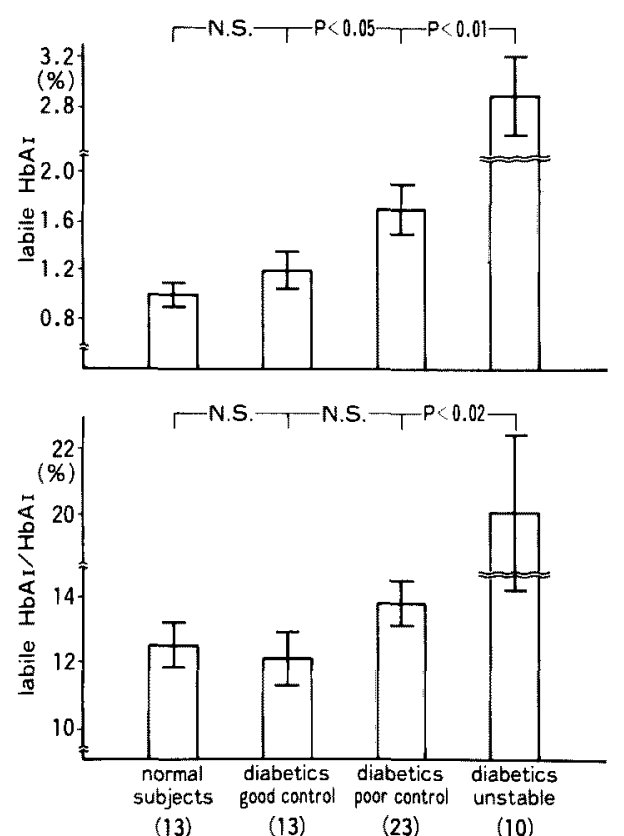

Fig 1. Rapid changes of $\mathrm{HbAI}$ and HbAIc in normal subjects and diabetic patients.

Parentheses represent the number of cases. The data represent the mean \pm S.E. 


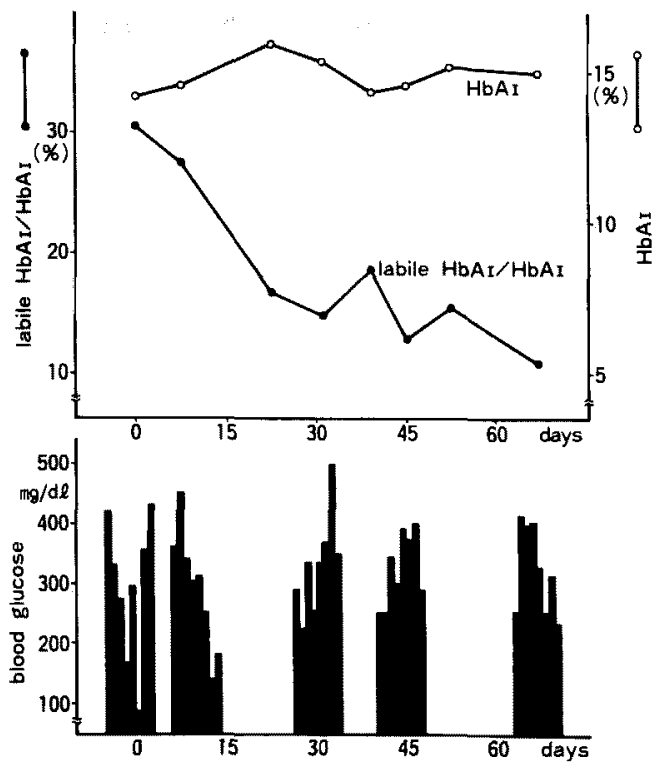

Fig 2. Clinical course of a case of unstable diabetes.

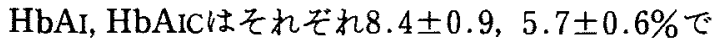
あつた。

HbAI 中に存在するlabile $\mathrm{HbAl}$ 分画の測定か ら (Fig 1), labile HbAI分画は糖㽷病症例では健 常者に比べて高値を示し，血糖コントロール良好 な糖疗病症例よりも血糖コントロール不良例が高 值であつた。一方，HbAI值に占めるlabile HbAI 值（labile $\mathrm{HbAI} / \mathrm{HbAI} \times 100 ）$ は血糖コントロー ル不良群では13.8土1.4\%と，健常者群12.5土 $1.4 \%$ (Mean $\pm \mathrm{SE}$ ) との間に有意の差はみられな からた，血糖コントロール不安定型糖㽷病症例で はlabile $\mathrm{HbAI}$, 並びにlabile $\mathrm{HbAI} / \mathrm{HbAI}$ 值も共 に健常者群括よび血糖コントロール不良，あるい は良好群に比べて有意に高值を示した。

Fig 2は26才の不安定型糖尿病症例の臨床経過 と，HbAIお。びlabile HbAI/HbAIを示したもの である，本例は出産後不安定型糖㽷病状態を呈し た、入院時は血糖の日内変動が著明であつたが， 各種の治療によつて血糖の日内変動がやや少なく なつてきたが，血糖值あるいはM値は依然高值を 持続した。これに対して，HbAIは高值のまま推移 したが, labile $\mathrm{HbAl} / \mathrm{HbAI}$ 入院時 $30.7 \% か ら ，$
第45〜60病日にはほぼ健常者のレベルに低下し た.

\section{考案}

HbAIおよびHbAIcは，Hbとグルコースの非醳 素的な結合によつて徐々に生成されることから， 糖尿病の長期の血糖コントロールの指標になりら

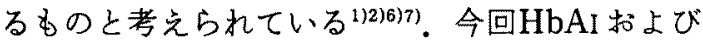
HbAIcが過去のいつの血糖コントロールを最も よく反映しているのかを判定しょうと試みた。こ のよらな検討には対象とした症例によつて多少成 䋶が異なる可能性があるため，ケトアシドーシス あるいは不安定型糖尿病症例を除いた多数の糖尿 病症例でHbAI 括よびHbAIC を測定した。ささらに HbAI, HbAIC を測定した時点よりさかのぼつた 8 週以前の各時点でのFBSとの相関をみた。 $\mathrm{HbAI}$ 括よびHbAIC は $3 \sim 4$ 週前の各時点のFBS との間に最す良好な相関を示し，以前に我々が報 告した成績のと同様に，HbAIおよびHbAICは約 1 カ月前の血糖コントロール状態を最もよく反映し ているものと考えられた。

HbAIあるいはHbAIC を血糖コントロール指標 として用いる場合，HbAI およびHbAICを健常者 レベルにまで低下させることを目標とすると，低 血糖を生ずる可能性があり，どれ程までHbAI 招 よびHbAICを低下させればよいかという問題が あるが，この問題に明確な回答を行なつたるのは 少ない. 我々は正常者の $\mathrm{HbAI}$ の変動域を考慮し, 血糖のコントロール良好例の HbAI, HbAIC の平 均值9.2，6.1\%を参考にし，HbAIで 9\%, HbAIC で $6 \%$ 以下をコントロール目標と考えた。な报， これらの值はimpaired glucose tolerance群の $\mathrm{HbAI}$ あるいHbAIC の平均值よりは高値であつ た。今回，血糖コントロール良好例を選択したに もかかわらず，HbAIは 7 から $12 \%$, HbAICは4.5 から8.5\%の間に分布していた。この事実は，血糖 コントロール良好例においても長期間の間には, FBSでは把握しえない血糖の上昇が存在してい たことを示しているのではないかと考充られ，血 糖測定では表現し壳ない血糖のコントロール指標 としての HbAI，あるいはHbAICの有用性を示し 
ているものと思われる。

最近, HbAIにはSchiff base結合の一部に，血 糖の変動につれて可逆的に変動するlabile HbAI が存在し、これは主としてHbAIC分画に存在する あのと考党られてきた. Goldsteinら ${ }^{8)}$ は, HbAIC の10 20\%がlabile HbAIであろ5と述べている が，今回の成績からは，極端な血糖変動を示す場 合の他は，糖尿病の血糖コントロール良好例，血 糖コントロール不良例共に, HbAIK占めるlabile HbAIの比率に有意差はみられず， labile $\mathrm{HbAI} /$ HbAI × 100は約 $13 \%$ と考光られた。この事実から は, HbAlの臨床坎用において, labile HbAIを常 に除去する必要は少ないるのと考兄られた，不安 定型糖尿病症例のlabile $\mathrm{HbAI}$ が高值を呈するの は, $\mathrm{Hb}$ そグルコースの結合が可逆性であり, 実験 的にも赤血球を高グルコースあるいはグルコース を除去したmediumでincubationする場合，数時 間でlabile HbAlが生成されたり除去される89)。 の事実を考えると，不安定型糖尿病症例でlabile HbAI が高値を示した事実は, 血糖の変動が顕著 な場合に，低血糖の期間よりも，むしろ一日のう ちでは高血糖の期間が長いためなのか，あるいは Schiff base結合のHbからグルコースが解離する

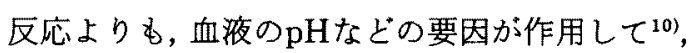
Hbにグルュースが結合する反応が容易に進行す るためではないかとも考えられる。

以上のように糖尿病症例で, labile HbAI並びに labile $\mathrm{HbAl} / \mathrm{HbAI} \times 100$ を観察することにより， 最近の血糖コントロールの不安定状態の有無を判 定することが可能になるものと思われる.

\section{結 論}

本研究によつて次の事が結論された。

1）HbAIあるいはHbAIC は糖尿病患者の約 1
カ月前の血糖コントロール状態を示す指標とな る.

2) 糖尿病患者の血糖コントロールの目標值は HbAIで $9 \%$, HbAICで $6 \%$ とした。

3）精尿病患者では， labile $\mathrm{HbAI} / \mathrm{HbAI}$ 健常 者との間に差はなく，約13\%であつた。

4) 不安定型糖尿病症例では, labile HbAI值お よびlabile $\mathrm{HbAI} / \mathrm{HbAl}$ 大であつた.

\section{文献}

1) Koenig RT, et al: Correlation of glucose regulation and hemoglobin Alc in diabetes mellitus. New Engl J Med 295 : 417, 1976.

2) Gabbay $\mathrm{KH}$, et al: Glycosylated hemoglobin and long-term blood glucose control in diabetes mellitus. J Clin Endocrinol Metab 44 : 859, 1977.

3) Cole RA, et al: A rapid method for the determination of glycosylated hemoglobins using high pressure liquid chromatography. Metabolism 27: 289, 1978.

4）老籹宗忠，他： $\mathrm{HbA}_{1}$ 分画测定の意義. 糖尿病 $24: 989,1981$.

5) Nathan DM, et al: A rapid chemical means for removing labile glycohemoglobin. Diabetes $30: 700,1981$.

6）老数宗忠，他：糖尿病患者に抢けるglycosylated hemoglobin 及び赤血球2, 3-diphosphoglycerate の䠛末的意義比関する研究. 糖尿病 $22: 677$, 1979.

7) Gonen G, et al: Hemoglobin Al. An indicator of the metabolic control of diabetic patients. Lancet ii : 734, 1977.

8) Goldstein DE, et al : Effect of acute changes in blood glucose on HbAlc. Diabetes 29 : 623, 1980.

9) Svendsen PA, et al: Rapid changes in chromatographically determined hemoglobin Alc induced by short-term changes in glucose concentration. Diabetologia $19: 130,1980$.

10）老数宗忠，他：腎不全患者に招けるglycosylated hemoglobin. 日腎誌 $22: 259,1980$. 